\title{
Instytuty badawcze jako forma działalności naukowej i gospodarczej państwa - problematyka pozycji i formy prawnej
}

The research institutes as a form of scientific and economic State activity - the problem of their position and legal form

Streszczenie. Instytuty badawcze są państwowymi jednostkami organizacyjnymi posiadającymi osobowość prawną, powoływanymi w celu prowadzenia badań naukowych ukierunkowanych na gospodarcze zastosowanie. W obecnym stanie prawnym są podmiotami pozostającymi poza sektorem finansów publicznych. Stan ten może budzić wątpliwości. W artykule poddano analizie status prawny instytutów badawczych i charakter prowadzonej przez nie działalności.

Słowa kluczowe: instytut badawczy, sektor finansów publicznych.

Abstract. The research institutes are state-owned legal persons, created to conduct research focused on the economic use. They aren't in public finance sector 
now. This might raise doubts. The article analyzes the legal status of research institutes and the character of their activities.

Keywords: the research institute, public finance sector.

\section{Wstęp}

Podstawą rozwoju gospodarczego każdego państwa jest postęp naukowy. Rolą państwa jest jego wspieranie w różnych formach. Jedną z nich jest bezpośrednie angażowanie się państwa w prowadzenie działalności naukowo-badawczej ukierunkowanej na wsparcie dla gospodarki.

Formą organizacyjno-prawną prowadzenia działalności naukowobadawczej mającej na celu wspieranie gospodarki jest instytut badawczy, podlegający ministrowi. Są różne rodzaje instytutów: instytuty naukowe Polskiej Akademii Nauk, instytuty szkół wyższych oraz samodzielne instytuty badawcze, określane jako „resortowe”, czyli podlegające określonym ministrom. Wszystkie instytuty prowadzą działalność naukową, ale występuje różnica pomiędzy działalnością instytutów PAN i szkół wyższych, które są zorientowane na rozwój nauki sam w sobie, a działalnością instytutów resortowych, które mają na celu dostarczanie konkretnych rozwiązań dla potrzeb gospodarki.

Przedmiotem opracowania będą resortowe instytuty badawcze. W opracowaniu zostanie poddany analizie ich status prawny związany ze specyficzną działalnością, którą podmioty te prowadzą.

\section{Zarys historyczny}

Tworzenie instytutów badawczych ma długą tradycję. Wskazuje się, że pierwsze takie jednostki powstały na ziemiach polskich w II poł. XIX w. ${ }^{1}$ W okresie II Rzeczypospolitej istniało 15 instytutów naukowo-badawczych,

A. Niewęgłowski, Wyniki prac badawczych w obrocie cywilnoprawnym, Warszawa 2010, s. 74. 
w tym 7 technicznych ${ }^{2}$. Były to m.in. Państwowy Instytut Meteorologicz$n^{3}{ }^{3}$, Instytut Torfowy ${ }^{4}$ oraz Państwowy Instytut Naukowy Gospodarstwa Wiejskiego w Puławach ${ }^{5}$ (działające przy Ministerstwie Rolnictwa i Dóbr Państwowych), Państwowy Zakład Higjeny ${ }^{6}$ (podlegający Ministrowi Opieki Społecznej), Państwowy Instytut Geologiczny ${ }^{7}$ oraz Instytut Badań Konjunktur Gospodarczych i $\mathrm{Cen}^{8}$ (podległe Ministrowi Przemysłu i Handlu). Wszystkie one zostały zniszczone w trakcie II wojny światowej ${ }^{9}$.

Po wojnie nastąpił rozwój resortowych instytutów badawczych, wynikający m.in. z potrzeby odbudowy gospodarki z doznanych zniszczeń. W latach 1944-1951 powstało 58 placówek naukowo-badawczych ${ }^{10}$. Ich liczba wzrastała w dalszych latach, chociaż w wolniejszym tempie. W 1988 r. istniało 120 resortowych i branżowych instytutów badawczych ${ }^{11}$.

W pierwszych latach powojennych instytuty resortowe powoływano odrębnymi aktami ustawodawczymi ${ }^{12}$. Następnie stworzono podstawy prawne do tworzenia samodzielnych placówek naukowo-badawczych podlegających ministrowi właściwemu do spraw oświaty ${ }^{13}$. W przemyśle tworzono Główne Instytuty Naukowo-Badawcze Przemysłu podlegające

2 Z. Ostrowski, Badania naukowe i prace rozwojowe w gospodarce narodowej, Warszawa 1968, s. 35-36.

3 Ustawa z dnia 23 maja 1922 r. w przedmiocie statutu Państwowego Instytutu Meteorologicznego (Dz.U. z 1922 r. Nr 44, poz. 373).

4 Rozporządzenie Rady Ministrów z dnia 8 kwietnia 1919 r. w przedmiocie utworzenia Instytut Torfowego (Dz.U. z 1919 r. Nr 34, poz. 271).

5 Ustawa z dnia 28 października 1921 r. statut Państwowego Instytutu Naukowego Gospodarstwa Wiejskiego w Puławach (Dz.U. 1921 r. Nr 93, poz. 684).

6 Rozporządzenie z mocą ustawy Prezydenta RP z dnia 10 czerwca 1927 r. o Państwowym Zakładzie Higjeny (Dz.U. z 1936 r. Nr 45, poz. 336 ze zm.).

7 Rozporządzenie Rady Ministrów z dnia 28 lutego 1921 r. w przedmiocie zatwierdzenia statutu Państwowego Instytut Geologicznego (M.P. z 1921 r. Nr 65, s. 1).

8 Rozporządzenie z mocą ustawy Prezydenta RP z dnia 15 lutego 1928 r. o ustanowieniu Instytutu Badania Konjunktur Gospodarczych i Cen (Dz.U. z 1928 r. Nr 17, poz. 144).

Z. Ostrowski, Badania naukowe..., s. 36.

10 Tamże, s. 37.

11 Główny Urząd Statystyczny, Jednostki badawczo-rozwojowe w 1988 r., Warszawa 1989, s. 6.

12 W. Wepsięć, Organizacja i finansowanie działalności badawczo-rozwojowej [w]: M. Weralski (red.), System instytucji prawno-finansowych PRL. Tom IV: Instytucje socjalistycznych jednostek gospodarczych, Wrocław 1987, s. 506.

13 Dekret z mocą ustawy Rady Ministrów z dnia 28 października 1947 r. o organizacji nauki i szkolnictwa wyższego (Dz.U. z 1947 r. Nr 66, poz. 415 ze zm.). 
Ministrowi Przemysłu i Handlu ${ }^{14}$, a w budownictwie instytuty naukowobadawcze dla budownictwa podlegające Ministrowi Budownictwa ${ }^{15}$. W 1951 r. zniesiono Główne Instytuty Naukowo-Badawcze Przemysłu, które zastąpiono instytutami naukowo-badawczymi ${ }^{16}$. W 1961 r. $^{17}$ nastąpiła pełna unifikacja podstaw prawnych tworzenia resortowych instytutów naukowo-badawczych ${ }^{18}$. Były dwa rodzaje takich instytutów: instytuty o międzybranżowym profilu działalności, zarządzane bezpośrednio przez poszczególne resorty, oraz instytuty branżowe, zarządzane przez zjednoczenia będące organizacjami gospodarczymi grupującymi przedsiębiorstwa $^{19}$. Kolejną podstawą prawną działalności instytutów naukowobadawczych była ustawa z 1985 r. o jednostkach badawczo-rozwojowych $^{20}$. W świetle ustawy jednostkami badawczo-rozwojowymi były instytuty naukowo-badawcze, a także ośrodki badawczo-rozwojowe ${ }^{21}$, centralne laboratoria i inne jednostki organizacyjne, których podstawowym zadaniem było prowadzenie działalności naukowo-badawczej ukierunkowanej na wspieranie gospodarki.

Przemiany ustrojowe i gospodarcze po 1989 r. wywarły wpływ na instytuty badawcze. Znalazły się one w nowej rzeczywistości gospodarczej. Przedsiębiorstwa państwowe, będące podstawą gospodarki PRL, zaczęły tracić na znaczeniu. Państwo zaczęło wycofywać się z prowadzenia działalności gospodarczej, pozostawiając ją sektorowi prywatnemu. Do gospodarki zaczął również napływać kapitał zagraniczny, który preferował

14 Dekret z dnia 25 października 1948 r. o tworzeniu Głównych Instytutów NaukowoBadawczych Przemysłu (Dz.U. z 1948 r. Nr 50, poz. 388).

15 Ustawa z dnia 27 kwietnia 1949 r. o utworzeniu Urzędu Ministra Budownictwa (Dz.U. z 1949 r. Nr 30, poz. 216).

16 Ustawa z dnia 8 stycznia 1951 r. o tworzeniu instytutów naukowo-badawczych dla potrzeb gospodarki narodowej (Dz.U. Nr 5, poz. 38).

17 Na mocy ustawy z dnia 17 lutego 1961 r. o instytutach naukowo-badawczych (Dz.U. z 1961 r. Nr 12, poz. 60 ze zm.).

18 W. Wepsięć, Organizacja i finansowanie..., s. 506.

19 Z. Ostrowski, Badania naukowe..., s. 66, 97.

20 Ustawa z dnia 25 lipca 1985 r. (Dz.U. z 2008 r. Nr 159, poz. 993 ze zm.).

21 Zgodnie z uchwałą Rady Ministrów z dnia 24 listopada 1970 r., M.P. Nr 34, poz. 340 ze zm., ośrodki badawczo-rozwojowe mogły być tworzone w celu kompleksowego prowadzenia prac naukowo-badawczych, konstrukcyjnych, technologiczno-projektowych i doświadczalnych w określonej dziedzinie lub branży gospodarczej. 
przejęcie państwowych podmiotów badawczo-rozwojowych poprzez prywatyzację niż korzystanie $\mathrm{z}$ ich usług jako podmiotów zewnętrznych ${ }^{22}$. Powodowało to utratę dotychczasowych odbiorców usług jednostek badawczo-rozwojowych. Pojawiła się potrzeba ich zreformowania, aby dostosować je do nowej sytuacji gospodarczej. Nowelizacje ustawy o jednostkach badawczo-rozwojowych z lat 2000 i 2007 stworzyły podstawę do przekształceń strukturalnych i własnościowych, lecz reformy okazały się niewystarczające ${ }^{23}$. Ostatecznie ustawodawca zdecydował o zastąpieniu tej ustawy ustawą z dnia 30 kwietnia 2010 r. ${ }^{24}$ o instytutach badawczych, która obowiązuje do chwili obecnej. Stworzono również podstawy do zmniejszenia liczby jednostek badawczo-rozwojowych poprzez ich przekształcenia, komercjalizację lub likwidację. W świetle ustawy Przepisy wprowadzające ustawy reformujące system nauki ${ }^{25}$ jednostki, które otrzymały kategorię naukową 5 na podstawie przepisów ustawy z dnia 8 października 2004 r. o zasadach finansowania nauki, podlegały włączeniu do innych jednostek (instytutu badawczego, uczelni publicznej lub instytutu naukowego PAN), przekształceniu w inną formę organizacyjnoprawną (instytucję gospodarki budżetowej, instytut naukowy PAN), komercjalizacji lub likwidacji, w terminie 18 miesięcy od wejścia w życie ustawy o instytutach badawczych. Ustawa o instytutach badawczych otworzyła je również na współpracę z kapitałem prywatnym. Wprowadziła możliwość komercjalizacji i prywatyzacji instytutów, a także umożliwiła im tworzenie spółek kapitałowych w celu komercjalizacji wyników badań naukowych.

Formą współpracy instytutów badawczych z sektorem prywatnym są również centra naukowo-przemysłowe, które mogą być tworzone w drodze umowy zawieranej między podmiotami wchodzącymi w skład cen-

22 A. Matczewski, Popyt i podaż polskiego systemu innowacji a szanse podnoszenia poziomu innowacyjności gospodarki i budowania gospodarki opartej na wiedzy, [w:] E. Okoń-Horodyńska, Rola polskiej nauki we wzroście innowacyjności gospodarki, Warszawa 2004, s. 232-233.

23 Uzasadnienie do projektu ustawy o instytutach badawczych, druk sejmowy VI kadencji $\mathrm{nr}$ 1629, s. 52, http://orka.sejm.gov.pl/Druki6ka.nsf/0/533FC66012C2F1D3C 125754E0047BF7C/\$file/1629.pdf, (dostęp: 2.01.2016 r.).

24 Dz.U. z 2010 r., poz. 1095, dalej: u.i.b.

25 Ustawa z dnia 30 kwietnia 2010 r. (Dz.U. z 2010 r. Nr 96, poz. 620 ze zm.). 
trów w celu realizacji zadań takich jak: współdziałanie w realizacji wdrożeń wyników prac naukowo-technicznych, inicjowanie tworzenia i korzystania z dużej infrastruktury badawczej, realizacja programów staży pracowników naukowych, wspieranie i koordynowanie działalności podmiotów wchodzących w skład centrum i in. W skład centrów mogą wchodzić również uczelnie i instytuty naukowe PAN oraz zagraniczne instytucje naukowe. Podmioty wchodzące w skład centrum mogą współpracować w formie klastrów, parków technologicznych, platform technologicznych i w innych formach organizowania się, odpowiadających celom i przedmiotowi ich działalności.

Według stanu na 8 stycznia 2016 r. w Polsce działało 116 resortowych instytutów badawczych ${ }^{26}$.

\section{Instytuty badawcze - stan de lege lata}

Ustawa z dnia 30 kwietnia 2010 r. o instytutach badawczych według stanu prawnego na 8 stycznia 2016 r. zawiera 68 artykułów ujętych w 10 rozdziałach. Przedmiotem regulacji ustawy jest określenie formy organizacyjno-prawnej tych jednostek, realizowanych przez nie zadań, procedury tworzenia oraz przekształceń strukturalnych, takich jak: przekształcenie w inną formę organizacyjno-prawną, połączenie lub włączenie do innej jednostki, komercjalizacja i prywatyzacja, likwidacja. Ustawa określa również zasady gospodarki instytutów, ich organy, stosunki pracownicze, kwestie nadzoru i inne. Ustawa ta jest powiązana $\mathrm{z}$ innymi ustawami regulującymi kwestie nauki, badań naukowych, ich organizacji i finansowania, zwłaszcza z ustawą o zasadach finansowania nauki ${ }^{27}$.

W świetle aktualnej ustawy o instytutach badawczych są one państwowymi jednostkami organizacyjnymi wyodrębnionymi pod względem prawnym, organizacyjnym i ekonomiczno-finansowym, które prowadzą badania naukowe i prace rozwojowe ukierunkowane na ich wdrożenie i zastosowanie w praktyce (art. 1 ust. 1 u.i.b.). Instytuty badawcze posia-

26 http://www.rgib.org.pl/index.php?option=com_sobi2\&Itemid, dostęp: 8.01 .2016 r.

27 Ustawa z dnia 30 kwietna 2010 r. (tekst jedn. Dz.U. z 2014 r., poz. 1620 ze zm.). 
dają osobowość prawną, którą nabywają z chwilą wpisu do Krajowego Rejestru Sądowego (art. 1 ust. 2 u.i.b.).

Status prawny instytutów badawczych jako państwowych osób prawnych jest wyrazem przynależności sfery nauki i prowadzenia badań naukowych do zadań państwa. Instytut może być utworzony przez Radę Ministrów w formie rozporządzenia na wniosek ministra właściwego ze względu na planowaną działalność instytutu, po zasięgnięciu opinii ministra właściwego do spraw nauki. Utworzenie instytutu może nastąpić, jeżeli zaistnieje potrzeba prowadzenia w danej dziedzinie działalności badawczej oraz zostanie zapewniona niezbędna kadra o odpowiednich kwalifikacjach oraz aparatura badawcza, laboratoryjna, potencjał informatyczny i inne niezbędne warunki materialno-techniczne (art. $4 \mathrm{i}$ art. 5 u.i.b.). Ministrem nadzorującym instytut jest minister wskazany w rozporządzeniu Rady Ministrów tworzącym instytut.

Instytut może otrzymać status państwowego instytutu badawczego, jeżeli zaistnieje potrzeba zlecenia mu zadań szczególnie ważnych dla państwa, dotyczących bezpieczeństwa i porządku publicznego, wymiaru sprawiedliwości, edukacji, kultury i innych, do wykonywania w sposób ciągły. Zadania te mogą dotyczyć m.in. opracowywania i opiniowania standardów w zakresie rynku pracy, ochrony zdrowia, środowiska, gospodarki żywnościowej i in., a także monitoringu i zapobiegania skutkom zjawisk i wydarzeń mogących stwarzać zagrożenie publiczne. Status państwowego instytutu badawczego nadaje Rada Ministrów w drodze rozporządzenia na wniosek ministra nadzorującego po uzgodnieniu z ministrem właściwym do spraw nauki oraz ministrem właściwym do spraw finansów publicznych. Nadając status państwowego instytutu badawczego, Rada Ministrów określa zakres zadań tego instytutu, źródła finansowania i wskazuje dysponentów środków budżetowych przeznaczonych na realizację tych zadań. Na realizację zleconych zadań państwowy instytut badawczy otrzymuje dotację celową z budżet państwa.

Instytuty mogą prowadzić działalność podstawową oraz działalność inną niż podstawowa. Do podstawowej działalności instytutu należy:

1. prowadzenie badań naukowych i prac rozwojowych, 
2. przystosowywanie wyników badań naukowych i prac rozwojowych do potrzeb praktyki,

3. wdrażanie wyników badań naukowych i prac rozwojowych.

Pojęcia „badania naukowe” oraz „prace rozwojowe” zostały zdefiniowane w ustawie z dnia 30 kwietnia 2010 r. o zasadach finansowania nauki. Badania naukowe dzielą się na podstawowe, stosowane i przemysłowe. Badania podstawowe to oryginalne prace badawcze eksperymentalne lub teoretyczne podejmowane przede wszystkim w celu zdobywania nowej wiedzy, bez nastawienia na bezpośrednie zastosowanie komercyjne. Badaniami stosowanymi są prace badawcze podejmowane w celu zdobycia nowej wiedzy, zorientowane przede wszystkim na zastosowanie w praktyce. Badania przemysłowe są ukierunkowane na opracowanie produktów, procesów i usług lub wprowadzania znaczących ulepszeń do nich. Celem prac rozwojowych jest - ogólnie ujmując - zastosowanie dostępnej wiedzy naukowej, technologicznej i innej do planowania produkcji oraz tworzenia i projektowania nowych, zmienionych lub ulepszonych produktów, procesów i usług. W szczególności mogą one obejmować opracowywanie prototypów i projektów pilotażowych w celu ich dalszego udoskonalania lub w celu komercyjnego wykorzystania.

Zgodnie z art. 2 ustawy o instytutach badawczych w związku z działalnością podstawową instytuty mogą upowszechniać wyniki swoich badań, wykonywać badania, analizy, opracowywać opinie i ekspertyzy w zakresie prowadzonych badań naukowych i prac rozwojowych, prowadzić działalność normalizacyjną, certyfikacyjną, wytwarzać materiały i aparaturę potrzebną do badań itp. Ponadto instytuty mogą prowadzić studia podyplomowe i doktoranckie, związane z prowadzonymi przez instytut badaniami naukowymi i pracami rozwojowymi, oraz inne formy kształcenia. Poza działalnością podstawową instytuty mogą prowadzić inną działalność, która powinna być wyodrębniona pod względem finansowym i rachunkowym z działalności podstawowej. Taką inną działalnością instytutu może być działalność gospodarcza ${ }^{28}$.

28 D. Michta, Komentarz do art. 2 ustawy o instytutach badawczych, [w:] D. Michta, Ustawa o instytutach badawczych. Komentarz, LEX 2013. 
Instytut jest osobą prawną odpowiedzialną za własne zobowiązania, występującą w obrocie we własnym imieniu i na własny rachunek. Pokrywa koszty bieżącej działalności z uzyskiwanych przychodów. Przychody mogą być osiągane w związku z prowadzeniem działalności podstawowej i innej, w tym m.in. ze sprzedaży wyników badań naukowych i prac rozwojowych, patentów, praw ochronnych oraz licencji, prac wdrożeniowych, produkcji urządzeń i aparatury oraz innej produkcji lub usług. Przychody instytutu mogą również pochodzić z dotacji z budżetu państwa udzielanej na podstawie przepisów ustawy z dnia 30 kwietnia $2010 \mathrm{r}$. o zasadach finansowania nauki oraz ustawy z dnia 27 sierpnia 2009 r. o finansach publicznych ${ }^{29}$.

\section{Charakter działalności instytutów badawczych a ich forma prawna}

Działalność instytutów badawczych posiada szczególny charakter. Sytuuje się ona na styku działalności naukowej i działalności gospodarczej. Pojawia się pytanie, czy instytuty badawcze prowadzą działalność gospodarczą, czy są przedsiębiorcami? Można zauważyć, że z formalno-prawnego punktu widzenia instytuty badawcze są uznawane za przedsiębiorców. Zgodnie z ustawą o instytutach badawczych podlegają one wpisowi do Krajowego Rejestru Sądowego, gdzie są ujmowane w rejestrze przedsiębiorców ${ }^{30}$. Jednak kryterium zaliczenia do rejestru przedsiębiorców jest - jak podkreśla się w doktrynie - kryterium formalnym, ponieważ decyduje o nim forma prawna prowadzonej działalności, nie zaś rodzaj tej działalności ${ }^{31}$.

Instytuty badawcze $\mathrm{w}$ aktualnym stanie prawnym są państwowymi osobami prawnymi, ale nie należą do sektora finansów publicznych. Są one formami publiczno-prawnymi, specjalnymi i odrębnymi od innych form prawnych, takich jak przedsiębiorstwa państwowe, spółki prawa handlowego, zakłady, instytucje kultury, fundacje, agencje. Pojęcie „sektor finansów

\footnotetext{
29 Dz.U. z 2013 r., poz. 885 ze zm., dalej: u.f.p.

30 Art. 36 ustawy z dnia 20 sierpnia 1997 r. o Krajowym Rejestrze Sądowym (Dz.U. z 2015 r., poz. 1142 ze zm.).

31 A. Michnik, Ustawa o Krajowym Rejestrze Sqqdowym. Komentarz, Warszawa 2013, s. 271.
} 
publicznych” wprowadzono do polskiego ustawodawstwa 1 stycznia 1999 r., kiedy to weszła w życie ustawa o finansach publicznych z $1998 \mathrm{rr}^{32}$ Zaliczono do niego podmioty publiczne, tworzone przez państwo w celu wykonywania zadań publicznych, nieprowadzące działalności gospodarczej ${ }^{33}$. Początkowo objęte nim były również jednostki badawczo-rozwojowe (art. 4 ust. 1 pkt. 6 ustawy o finansach publicznych z $2005 \mathrm{r}^{34}$ ). Zostały z niego wyłączone od 2010 r., kiedy weszła w życie ustawa o finansach publicznych z 2009 r. Zgodnie z art. 9 pkt. 14 u.f.p. z 2009 r. do sektora finansów publicznych należą państwowe lub samorządowe osoby prawne utworzone na podstawie odrębnych ustaw w celu wykonywania zadań publicznych, z wyłączeniem przedsiębiorstw, instytutów badawczych, banków i spółek prawa handlowego. Instytuty badawcze zostały zatem potraktowane podobnie jak podmioty należące do państwa prowadzące działalność gospodarczą - przedsiębiorstwa państwowe, banki i spółki prawa handlowego, które również pozostają poza sektorem finansów publicznych. Świadczy to o traktowaniu przez ustawodawcę działalności instytutów badawczych jak działalności zbliżonej do działalności gospodarczej. Z drugiej jednak strony fakt pozostawania przez pewien czas tych podmiotów w sektorze finansów publicznych może świadczyć również o niekomercyjnym charakterze ich działalności.

Za komercyjnym charakterem działalności instytutów badawczych przemawiać może fakt, że jej celem jest nie tylko prowadzenie badań, ale również sprzedaż ich wyników. Instytuty te nie prowadzą działalności naukowej dla samego tylko rozwoju nauki, ale także w celu gospodarczego zastosowania wyników badań. Występują one zatem w charakterze podmiotu gospodarczego dostarczającego konkretnych usług, które znajdują nabywców - podmioty (m.in. przedsiębiorców), które zgłaszają na nie popyt. Stopień wdrożenia wyników badań jest jednym z wyznaczników efektywności działalności instytutów. Można zatem zauważyć, że cel prowadzenia

32 M. Wróblewska, Komentarz do art. 9 ustawy o finansach publicznych, [w:] H. Dzwonkowski, G. Gołębiowski (red.), Ustawa o finansach publicznych. Komentarz prawno-finansowy, Warszawa 2014, s. 33.

33 Tamże, s. 35.

34 Ustawa z dnia 30 czerwca 2005 r. (Dz.U. Nr 249, poz. 2104 ze zm.). 
działalności przez instytuty badawcze jest różny od celu prowadzenia analogicznej działalności przez instytuty naukowe PAN oraz instytuty uczelni wyższych.

Instytut jest samodzielnym podmiotem, odpowiadającym za swoje zobowiązania. Za zobowiązania instytutu nie odpowiada Skarb Państwa z wyjątkiem przypadku likwidacji instytutu prowadzącego działalność w zakresie obronności, uczestniczącego w systemie ochrony zdrowia lub nieprowadzącego działalności gospodarczej (art. 18 ust. 5 u.i.b.). Instytuty mają swobodę w sprawach komercjalizacji wyników badań naukowych i prac rozwojowych. Czynności w tym zakresie mogą podejmować bez konieczności uzyskania zgody Ministra Skarbu Państwa (art. 17 ust. 1 u.i.b.). Zgoda taka jest natomiast wymagana w przypadku podejmowania innych czynności prawnych w zakresie rozporządzania składnikami aktywów trwałych o wartość przekraczającej 50000 euro. Jej brak skutkuje nieważnością czynności prawnej ${ }^{35}$.

Za element świadczący o gospodarczym charakterze działalności instytutu można uznać również sposób prowadzenia gospodarki finansowej. Zgodnie z ustawą o instytutach badawczych instytuty pokrywają koszty bieżącej działalności z uzyskiwanych przychodów. Mogą również otrzymywać dotacje podmiotowe i celowe z budżetu państwa na zasadach określonych w ustawie o zasadach finansowania nauki oraz o w ustawie o finansach publicznych. Ich działalność może również przynosić zysk. W przypadku ponoszenia strat instytuty mogą być zlikwidowane lub może być ogłoszona ich upadłość. Występuje zależność instytutów badawczych od państwa pod względem finansowym, organizacyjnym, majątkowym oraz decyzyjnym.

Jednak wydaje się, że działalności instytutu badawczego nie można uznać za działalność komercyjną. Głównym celem działalności instytutu jest prowadzenie badań naukowych. Instytut musi prowadzić działalność badawczą, nie można dowolnie zmienić przedmiotu tej działalności na niebadawczą, ale bardziej opłacalną. Również tworzone przez instytut spółki kapitałowe muszą prowadzić działalność związaną z działalnością badaw-

35 Art. 5a ustawy z dnia 8 sierpnia 1996 r. o zasadach wykonywania uprawnień przysługujących Skarbowi Państwa (Dz.U. z 2012 r., poz. 1224 ze zm.). 
czą prowadzoną przez instytut. Celem nadrzędnym powoływania instytutu jest prowadzenie badań naukowych służących państwu i gospodarce.

Instytut prowadzi działalność nastawioną na samofinansowanie, co można rozumieć jako status pośredni między działalnością nieuwzględniającą w ogóle aspektów gospodarczych (jaką prowadzą np. jednostki budżetowe) a działalnością komercyjną.

Instytuty badawcze nie są jedynymi podmiotami należącymi do państwa lub samorządu, które prowadzą działalność samofinansującą się. W obrębie sektora finansów publicznych pozostają samorządowe zakłady budżetowe oraz instytucje gospodarki budżetowej, które również wykonują swoje zadania odpłatnie, pokrywając koszty swojej działalności z przychodów własnych, z możliwością dotowania z budżetu (art. 15 i art. 23-24 u.f.p.). Przy tym samorządowe zakłady budżetowe nie posiadają osobowości prawnej i nie podlegają wpisowi do KRS, a instytucje gospodarki budżetowej są osobami prawnymi i podlegają wpisowi do KRS jako przedsiębiorcy. Natomiast instytuty badawcze prowadzące podobną działalność przynajmniej w świetle art. 9 pkt. 14 u.f.p. - pozostają poza sektorem finansów publicznych.

Działalność prowadzona przez instytuty wymaga nakładów finansowych oraz utrzymywania aparatury badawczej. Wpisane jest w nią ryzyko niepowodzenia prowadzonych badań. Spośród podmiotów prywatnych jedynie wielkie koncerny międzynarodowe są w stanie budować własne, silne ośrodki badawcze ${ }^{36}$. Wydaje się zatem, że ze względu na koszty i ryzyko działalność instytutów badawczych nie zawsze może być prowadzona na zasadzie komercyjnej.

\section{Podsumowanie}

Zdolność do utrzymywania efektywnego sektora badań i rozwoju świadczy o sile gospodarki danego państwa i jego dbałości o rozwój nauki i gospodarki. Na sektor ten składa się wiele podmiotów, zarówno mają-

36 Z. Sadowski, Współczesna rola innowacji w ujęciu teorii ekonomii, [w:] E. OkońHorodyńska, Rola polskiej nauki we wzroście innowacyjności gospodarki, Warszawa 2004, s. 50. 
cych formę publicznoprawną, (PAN i instytuty naukowe PAN czy uczelnie wyższe), jak i prywatnych przedsiębiorców posiadających zaplecze badawczo-rozwojowe. Resortowe instytuty badawcze są tymi, które są w największym stopniu ukierunkowane na wspieranie gospodarki.

Charakter działalności instytutów badawczych nie jest jednoznaczny. Jest to działalność państwa, która ze swojej istoty łączy cel publiczny z uwarunkowaniami gospodarczymi. Posiada elementy właściwe dla działalności komercyjnej, ale jednocześnie zawiera znaczny element celu publicznego w postaci zapewnienia zaplecza naukowo-badawczego działającego na potrzeby gospodarki. Potrzeba utrzymywania takiego zaplecza zależy od struktury i potrzeb gospodarki. Może się okazać, że działalność pewnych instytutów przestaje być potrzebna, albo że istnieją względy uzasadniające komercjalizację instytutu. Jednak wydaje się, że tego rodzaju kwestie nie przesądzają, że sama działalność instytutów ma charakter zarobkowy.

Instytut badawczy jest państwową jednostką organizacyjną wyposażoną w osobowość prawną. Jest to inna forma organizacyjno-prawna niż przedsiębiorstwa państwowe, spółki, instytucje kultury i in. Pozycja instytutu badawczego jako formy organizacyjno-prawnej jest wyznaczana przez charakter prowadzonej przez niego działalności oraz przez przepisy regulujące jego ustrój i relacje z organami państwa. Jest to podmiot powołany do prowadzenia badań naukowych, na działalność którego organy państwa mogą wywierać wpływ.

Z charakterem działalności instytutów badawczych wiąże się również kwestia ich przynależności do sektora finansów publicznych. Zostały one z niego wyłączone od 2010 r. Skutkiem pozostawania instytutów poza sektorem finansów publicznych jest m.in. nieobjęcie ich regułami obowiązującymi podmioty wewnątrz tego sektora, wyznaczanymi m.in. przez ustawę o finansach publicznych, nieujmowanie planów finansowych instytutów w ustawach budżetowych, a także niezaliczanie zobowiązań instytutów do państwowego długu publicznego. Wydaje się, że potraktowanie ich jak przedsiębiorców i wyłączenie z sektora finansów publicznych stanowi rozwiązanie kontrowersyjne, choć możliwe do zaakceptowania w obecnym 
stanie prawnym. Złożona natura działalności tych podmiotów stawia jednak pytanie, czy ich forma organizacyjna nie powinna być zróżnicowana.

\section{Bibliografia:}

Matczewski A., Popyt i podaż polskiego systemu innowacji a szanse podnoszenia poziomu innowacyjności gospodarki i budowania gospodarki opartej na wiedzy w: E. Okoń-Horodyńska, Rola polskiej nauki we wzroście innowacyjności gospodarki, Wydawnictwo Polskiego Towarzystwa Ekonomicznego, Warszawa 2004.

Michnik A., Ustawa o Krajowym Rejestrze Sqqdowym. Komentarz, Lex a Wolters Kluwer business, Warszawa 2013.

Michta D., Komentarz do art. 2 ustawy o instytutach badawczych, [w:] D. Michta, Ustawa o instytutach badawczych. Komentarz, LexisNexis, LEX 2013.

Niewęgłowski A., Wyniki prac badawczych w obrocie cywilnoprawnym, Oficyna a Wolters Kluwer business, Warszawa 2010.

Ostrowski Z., Badania naukowe i prace rozwojowe w gospodarce narodowej, Państwowe Wydawnictwo Ekonomiczne, Warszawa 1968.

Sadowski Z., Współczesna rola innowacji w ujęciu teorii ekonomii, [w:] E. OkońHorodyńska, Rola polskiej nauki we wzroście innowacyjności gospodarki, Wydawnictwo Polskiego Towarzystwa Ekonomicznego, Warszawa 2004.

Wepsięć W., Organizacja i finansowanie działalności badawczo-rozwojowej [w:] M. Weralski (red.), System instytucji prawno-finansowych PRL. Tom IV: Instytucje socjalistycznych jednostek gospodarczych, Zakład Narodowy im. Ossolińskich - Wydawnictwo, Wrocław [etc.] 1987.

Wróblewska M., Komentarz do art. 9 ustawy o finansach publicznych, [w:] H. Dzwonkowski, G. Gołębiowski (red.), Ustawa o finansach publicznych. Komentarz prawno-finansowy, Wydawnictwo Sejmowe, Warszawa 2014. 